\title{
老年者に打ける痴呆及び寝たきり状態が 心拍数概日リズムに及ぼす影響
}

\section{島本 順子 島本 博幸* 中村 英雄}

＜要 約> 器質的心疾患を認めない高齢者入院患者 88 名（70９8歳, 男 28 , 女 60 ）を痴呆, 寝たきり の有無により 4 群に分け，24時間連続心電図記録を行った。この 1 時間当りの平均分時心拍数より最小 自乗スペクトル法にて回帰余弦曲線を算出し, 痴呆及び寝たきり状態の有無が心拍数概日リズムに及ぼ す影響について検討し，以下の結論を得た。

1）心拍数概日リズムは全例，相関係数 0.750 以上と有意に余弦曲線表示し得た（ $p<0.001 ）$.

2）平均心拍数である mesor には 4 群間で有意差を認めなかった。

3）amplitudeで表される “日差” は痴呆の有無にかかわらず, 寝たきり（一）は㾛たきり（十）に比 し, 有意に大であった。寝たきり状態では daily activity 低下に伴い自律神経, 特に交感神経緊張の減退 を示すものと推定された。

4) acrophase は痴呆群で有意に大であり最大心拍数時相の遅れとして, 痴呆と心拍数概日リズムを司 る自律神経中枢変化との間に何らかの関係を示唆するものと考えられた.

Key words : 高齢者, 24時間連続記録心電図, 心拍数概日リズム, 痴呆, 寝たきり状態

老年者医療に対する関心は年々高まりつつあり，入 院患者も痴呆或は何等かの基礎疾患を基に寝たきりと なる症例が増加傾向にある。老化による自律神経系の 変化についての報告が散見されるが，方法的困難さの ため痴呆患者における自律神経異常の有無についての 検討は乏しい。また，寝たきり老人でみられる症状は 自律神経系, 内分泌, 代謝調節機構の变化を巻き込ん だ全身的な代謝性コントロールの異常と考えられてい る ${ }^{11}$.これまで, 我々は心肺に異常を認めない老年者に 心拍数日内リズムが存在することを認めており ${ }^{2)}$, 今 回, 痴呆及び誛たきり状態の有無が循環調節機能に及 ぼす影響を心拍数概日リズムの面より評価検討した。

\section{対象・方法}

対象は当院入院中で胸部レ線検査, 心電図, 断層心 エコー㘡にて器質的心疾患を認めず，24時間連続記録 心電図にて全例洞調律かつ 24 時間各 1 時間当りの総心 拍数に対する期外収縮数が $1 \%$ 以下であった高齢者 88


及び寝たきり状態の有無により，A 群：痴呆 $(-)$, 寝 たきり（一）30名, B 群：痴呆 $(+$ ）寝たきり (一)

Y. Shimamoto, H. Nakamura：中村病院内科

${ }^{*} \mathrm{H}$. Shimamoto : 広島大学医学部第一内科

受付日．1987．11．4：採用日．1988．1．29.
13名, C 群：痴呆 (一), 寝たきり (+) 15名, D 群： 痴呆 $(+)$, 寝たきり $(+) 30$ 名の 4 群に分類した。痴 呆の有無は長谷川式簡易痴呆評価スケールを用い，ス コア10点以下を痴呆 $(+)$ 群, 22 点以上を痴呆 $(-)$ 群とした。また，演たきり状態とは，脳血管障害後遺 症, 骨粗鬆症, 慢性関節リウマチ, 骨折による運動機 能障害のために 6 カ月以上寝たきり状態が持続し介助 なくベッドょり離床不能である症例を寝たきり（十） 群, 介助なく立位, 歩行可能例を寝たきり（一）群と 定義した。痴呆 $(+)$ の症例は Alzheimer 型老年痴呆, 脳血管痴呆, 混合型痴呆のみを対象とし，甲状腺疾患 等の代謝性疾患, 脳腫瘍, 頭部外傷, 感染による痴呆 例は除外した。 また，脳血管障害以外の糖尿病，パー キンソン病, 慢性アルコール中毒等の自律神経機能に 異常をきたしうる疾患例も対象より除外した。薬剤と して各種降圧剤, 向精神薬等の自律神経機能に影響を 及ぼしうる薬剤投与は, 検査の 4 週間以上前に中止し た。

24時間連続記録心電図（以下ホルター心電図）記録 はフクダ電子社製 SM-26を用い, 解析には同社製 SCM-270system を使用して全波形書き出しをもとに 各 1 時間毎の平均分時心拍数を算出した。期外収縮は $\mathrm{RR}$ 間隔が先行 16 心拍の平均 $\mathrm{RR}$ 間隔の $70 \%$ 以下にな るときと定義した。 
ホルター心電図記録日は午前 6 時起床，午後 9 時消 灯とし日常生活は食事時間を一定（ $8: 30,12: 30$, 16：30), 昼間はトイレ, 歩行は自由とし, 運動療法, 作業療法および整形外科的 rehabilitation は施行しな かった.

心拍数概日リズムを評価するために，時系列 1 時間 毎に単位時間平均分時心拍数を基に最小自乗スペクト ル法を用いて24時間周期の回帰余弦曲線を以下の如く 算出した (Fig. 1).

$\mathrm{Y}=\mathrm{M}+\mathrm{A} \cos \omega(\mathrm{t}-\boldsymbol{\phi})$

$\mathrm{M}=$ mesor (heart beats $/ \mathrm{min}$ )

$\mathrm{A}=$ amplitude (heart beats $/ \mathrm{min}$ )

$\phi=$ acrophase (clock hr)

$\omega=\pi / 12(/ \mathrm{hr})$

F-testによりその相関係数 $\mathrm{r}$ の有意性を検定した。 これら 3 つのパラメータである mesor, amplitude, acrophaseを $\mathrm{A} \sim \mathrm{D}$ 群の 4 群間にてWilcoxon $U$ 検 定を用いて比較し，危険率 $5 \%$ 以下を有意差ありと判 定した。尚, 本文中及び図に用いた統計量は平均値士

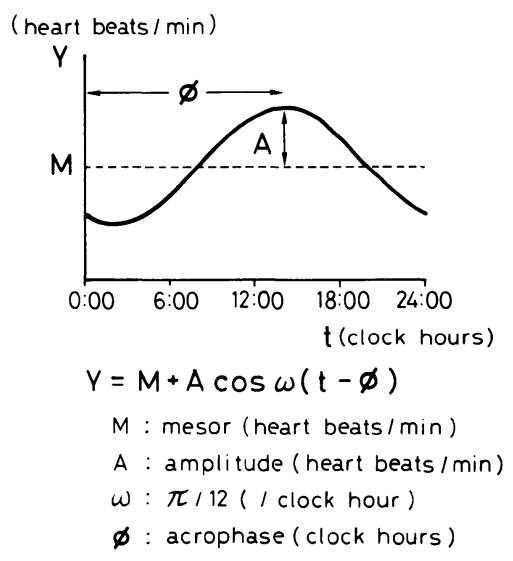

Fig. 1 Cosine curve by the statistical technique of least squares.
標準偏差を示した。

\section{成 績}

1）全例，心拍数概日リズムは相関係数 0.750 以上と 有意に余弦曲線表示し得た $(\mathrm{p}<0.001)$. 各 4 群におけ る mesor, amplitude, acrophase を示した(Table 1).

2）各群の mesor は 4 群間にて有意差は認められな かった (Fig. 2).

3） amplitude は寝たきり（一）の A 群，B群は, 寝 たきり（十）の C 群， D 群に比し各々有意に大であっ た $(\mathrm{p}<0.01)$.しかし, 寝たさり $(一) の A$ 群と B 群 間，及び唚たきり（十）の C 群と D 群間には有意差を 認めなかった（Fig. 3).さらに A，B両群を誛たきり （一）群， C, D 両群を寝たきり (十) 群とすると, 㾛 たきり（一）群10.09土2.67 heart beats $/ \mathrm{min}$ ，寝たき り（十）群6.65土2.74 heart beats $/ \mathrm{min}$ であり, 有意 に寝たきり（一）群が高值を示した（p<0.01）。

1 日最大心拍数 $=$ mesor + amplitude, 1 日最小心拍 数 $=$ mesor - amplitude と定義すると, A, B 両群の馒 たきり（一）群では各々 $80.37 \pm 10.51,60.18 \pm 8.36$ heart beats/min, C, D 両群の寝たきり $(+)$ 群では

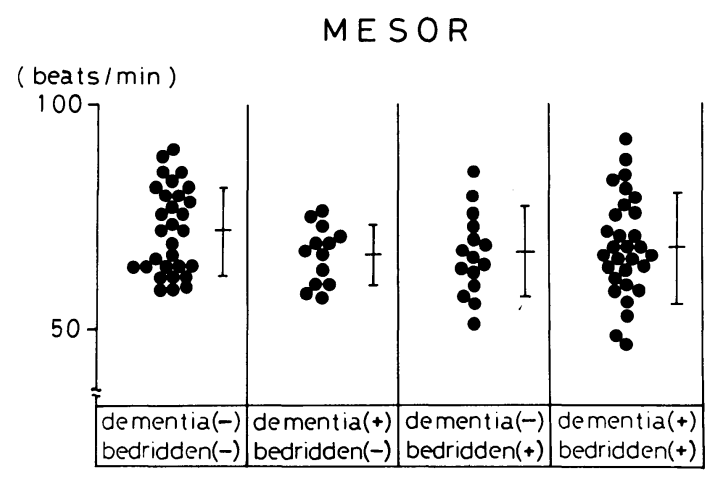

Fig. 2 Comparison of mesor among four groups. Mean \pm S.D.

Table 1 Comparison of circadian rhythm of heart rate among four groups. Mean \pm S.D.

\begin{tabular}{|c|c|c|c|c|c|c|c|}
\hline & 痴呆 & 寝たきり & $\mathrm{n}$ & mesor & amplitude & & acrophase \\
\hline & & & & (heart beats $/ \mathrm{min}$ ) & (heart beats $/ \mathrm{min}$ & & (clock hour) \\
\hline A 群 & - & - & 30 & $71.91 \pm 9.68$ & $9.79 \pm 2.50 \longrightarrow$ & & $14.98 \pm 1.1277$ \\
\hline B群 & + & - & 13 & $66.51 \pm 6.50$ & $10.79 \pm 3.00]$ & & $15.98 \pm 0.82$ \\
\hline C 群 & - & + & 15 & $66.79 \pm 9.13$ & $\left.5.96 \pm 1.98^{* *}\right]$ & ** & $14.98 \pm 2.16$ \\
\hline D群 & + & + & 30 & $68.55 \pm 11.05$ & $7.00 \pm 3.02$ & & $16.30 \pm 2.94$ \\
\hline
\end{tabular}

${ }^{*} \mathrm{p}<0.05, \quad{ }^{* *} \mathrm{p}<0.01$ 
AMPLITUDE

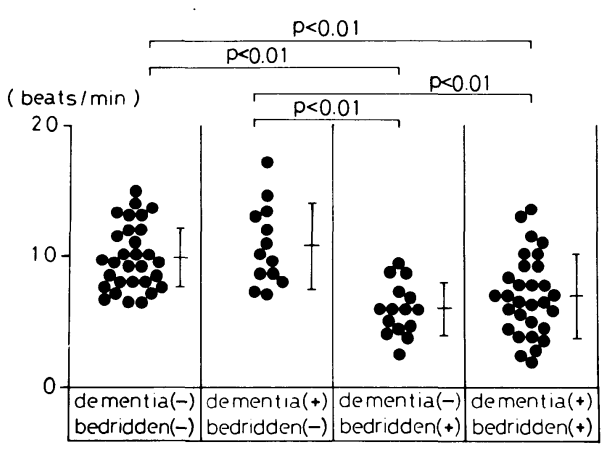

Fig. 3 Comparison of amplitude among four groups. Mean \pm S.D.

各々 $74.39 \pm 11.37,61.32 \pm 9.47$ heart beats $/ \mathrm{min}$ とな り，1 日最大心拍数は寝たきり (一) 群で有意に $(+)$ 群よりも大であったが $(\mathrm{p}<0.05) ， 1$ 日最小心拍数に は有意差を認めなかった。

4) acrophase は浸たきり（一）群の A， B 群間にて 痴呆 $(+)$ の B 群が有意に大であり $(\mathrm{p}<0.01)$ ，また， 痴呆，㾛たきり共に（一) の A 群より，共に（十）の $\mathrm{D}$ 群が有意に大であった $(\mathrm{p}<0.05)$ (Fig. 4). 更に A, $\mathrm{C}$ 両群を痴呆 $(一)$ 群, $\mathrm{B}, \mathrm{D}$ 両群を痴呆 $(+)$ 群とし て比較すると, 痴呆 (一) 群 $14.98 \pm 1.52$ clock hour, 痴呆 $(+)$ 群 $16.20 \pm 2.49$ clock hour であり, 痴呆 $(+)$ 群が有意に大であった $(\mathrm{p}<0.01)$. F 分布検定により 等分散の有無を検定したところ $\mathrm{AB}$ 群間， CD 群間は 等分散と推定されたが, $\mathrm{AC}$ 群間, $\mathrm{BD}$ 群間では $\mathrm{C}$ 群は $\mathrm{A}$ 群に比し，D群は B 群に比し分散が有意に大であっ た $(\mathrm{p}<0.01)$.したがって，痴呆の有無にかかわらず 寝たきり状態 $(+)$ 群では (一) 群に比し acrophase の 散らばりの度合が有意に大であった（ $\mathrm{p}<0.01 ）$.

\section{考察}

團たきり状態は単に運動機能障害のみならず，進行 的な中枢神経系の循環障害からくる機能低下，動脈硬 化による各器官の循環障害, 低酸素血症による機能低 下，これらによる痴呆，食欲低下，栄養不全を基盤と する退行性の重篤な変化であり, 自律神経系, 内分泌, 代謝調節機構異常と考えられる1).

一方, 疾呆とは知能機能の後天的障害で意識障害を 除いた状態であり，言語，記憶，視空間機能，人格， 認識の 5 つの機能のうち少なくとも 3 つが後天的かつ 持続的に障害される症候群と定義される ${ }^{3)}$. 老年痴呆
ACROPHASE

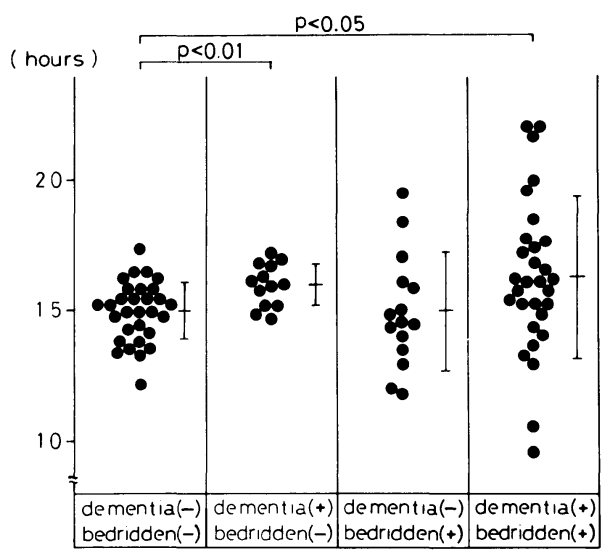

Fig. 4 Comparison of acrophase among four groups. Mean \pm S.D.

患者の増加に伴い, 老年痴呆と神経伝達物質の変化を 含めた自律神経系異常との関連が注目されてきてい る. 脳内の主要な神経伝達物質のうち, 脳内ノルエピ ネフリン作動系の指標と考えられる髄液 dopamine$\beta$-hydroxylase (DBH) 活性は, 多発梗塞痴呆では正 常範囲にあったが，Alzheimer 型老年痴呆では低値を 示したと報告されている。また, 血清 DBH 活性は末梢 性交感神経機能を反映すると考えられており，多発性 梗塞痴呆や65歳以上発症の老年痴呆では正常值である が, 65歳未満発症の Alzheimer 病では有意に低值であ り神経節を含めた末梢交感神経の機能不全を伴らこと が示唆されている4) 6). 一方, 主に副交感神経系の指標 と考えられている心電図 R-R 間隔変動係数を用いた 検索によると, Alzheimer 型老年疾呆では対照群に比 して有意に低値を示し自律神経障害の存在が考えられ ている6).さらに睡眠脳波の検討では老年者は睡眠が 浅く，これは自律神経機能低下と関係があり，痴呆の 程度が高度なほど睡眠障害が高頻度と報告されてい る7).

健常成人に於て心拍数が概日リズムを示し自律神経 を介する生体リズムにより調節されていることは広く 知られているが，著者らが既に報告したごとく老年者 にても心拍数概日リズムが存在し，ホルター心電図を 用いた最小自乗スペクトル法による解析が再現性ある 方法として臨床的に有用である2．今回，この方法を用 いて老年者における痴呆, 寝たさり状態が心拍数概日 リズムに及ぼす影響を検討し，自律神経系の変化を推 
測した。痴呆, 寝たきりの有無により mesorである平

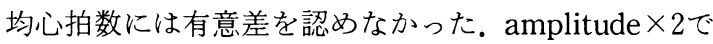
表される最大心拍数と最小心拍数の差である “日差” は，痴呆の有無にかかわらず寝たきり状態で有意に小 であった。一般に昼間は活動に適した交感神経緊張， 夜間は睡眠に適した副交感神経緊張という律動的変化 が心拍数概日リズムに強く関連しているが8)，寝たき り状態では daily activity 低下により交感神経緊張が 低下を来し， amplitude や最大心拍数が有意に低下し たものと考えられた。しかし，最小抢よび平均心拍数 は寝たきり状態による有意な変化はなく副交感神経活 動の関与は少ないものと考兄られた。

acrophase で表される最大心拍数時相は寝たきり (一) 群のらち, 痴呆 (+) 群は (一) 群に比し有意に 遅れ位相変位を示した。種々の実験成績から日内リズ 厶の中枢は鳥や哺乳類では視交叉上核, 松果体, 間脳, 下垂体にあるとされ，痴呆（十）群では日内リズム中 枢に血管性変化或は変性等の影響が及び，位相変位は 中枢の変化を反映したものと推定される。また，本研 究の対象とした誛たきり（一）群のうち痴呆（十）で は痴呆 (一) に比し夜間不穞, 徘徊例が多く存在して いた。一般に老年者に打ける不眠を含めた夜間行動異 常は痴呆状態や器質的障害と関連性が高く，44\%に脳 血管障害が存在するとの報告もあり9)，この様な夜間 精神, 行動異常が痴呆による日内リズム中枢の位相変 位の原因となる可能性，また逆に位相のずれの結果夜 間精神行動異常の引金になるとも考えられる。

一方, acrophase は寝たきり $(+)$ 群では $(-)$ 群に 比してばらつきの度合が有意に大であった。一般にヒ トにおける心拍数の日内変動の因子として, 自律神経 緊張の他に反射, 情動状態, 代謝因子, 化学媒体, 薬 物が挙げられている8). 痴呆の有無にかかわらず寝た きり（+）では，日内変動を規定する最大要因である 自律神経緊張, 特に昼間交感神経活動の低下のために, 心拍数概日リズムに影響を及ぼす自律神経緊張以外の 要因による作用が不均一に顕在化したためとも考兄ら れる。

今回の検討で痴呆, 寝たきり状態は心拍数概日リズ ム変化を来すことが示され，主に自律神経異常が表現 されたものと考兄れた。しかし，その原因は不明で
あり, 特に位相変位のメカニズムは多要因性と推定さ れ, 今後, さらに各要因の検討が必要と考えられる。

本研究の要旨は第29回日本老年医学会総会（1987年，大 阪）にて発表した。

\section{文献}

1）藤田拓男：老年者の内分泌疾患の見方とその特 徵. 臨床老年医学大系, 9巻. 村上元孝, 太田邦夫, 今堀和友 (編), 情報開発研究所, 東京, 1983, $219-242$.

2）島本順子, 島本博幸, 坂田省吾, 中村英雄：24時間 連続記録心電図を用いた高齢者心拍数概日リズム の検討. 広島大学医学雑誌 35：943-947, 1987.

3) Cummings JL, Benson DF, LoVerme $\mathrm{S} \mathrm{Jr}$ : Reversible dementia. JAMA $243: 2434-2439$, 1980.

4）中村重信, 宮田 学, 亀山正邦：不䯣意運動疾患に 扮ける血清 dopamine- $\beta$-hydroxylase, glutamic acid decarboxylase, L-aromatic amino acid decarboxylase について。臨床神経 19:511一 514, 1979.

5) Miyata $S$, Nagata $H$, Yamano $S$, Nakamura $S$, Kameyama M : Dopamine- $\beta$-hydroxylase activities in serum and cerebrospinal fluid of aged and demented patients. J Neurol Sci 63 : 403-409, 1984.

6）三森康世, 三森 倫, 貞包典子, 北澄忠雄, 嶋田和 幸, 斉藤 曻, 小沢利男, 宮田 学, 山尾 哲, 中 村重信, 亀山正邦：老年痴呆患者に打ける自律神 経異常 (抄)。日老医誌 $22 ： 88,1985$.

7）東京都老人総合研究所精神医学研究室：東京都に おける在宅ぼけ老人の社会精神医学的実態. 東京 都老人総合研究所, 1981.

8）木戸又三，雨宮克彦，守屋国光：老年病患者と夜間 の行動障害（老人病院における実態調査を中心と して). 精神経誌, 78：676-682, 1976.

9）加地正邦, 矢永尚士：発病のタイミング. 時間生物 学, 佐々木隆, 千葉喜彦(編), 朝倉書店, 東京, 1978, $294-311$. 
Abstract

\title{
The Influence of Dementia and Physical Disability on the Circadian Rhythm of Heart Rate in the Elderly
}

\author{
Yoriko Shimamoto, Hiroyuki Shimamoto* and Hideo Nakamura
}

The circadian rhythm of heart rate was assessed using 24 hour electrocardiographic recordings in 88 hospitalized elderly patinets without any organic heart diseases. To investigate the factors influencing the diurnal variation of heart rate, patients were classified on the basis of dementia and physical disability into four groups. To determine if heart rate fluctuates rhythmically with a circadian period, mean hourly heart rate in 24 hour electrocardiographic recordings was used to fit cosine curves by the statistical technique of least squares, and three parameters of the rhythm - designated the mesor, amplitude, and acrophase- were estimated. 1) The cosine curves were fitted with a $P$ value of 0.001 or less in all patients. 2) The mesor represented the rhythm-adjusted mean of heart rate. An analysis of the mesor revealed no significant difference

Department of Internal Medicine, Nakamura Hospital

* First Department of Internal Medicine, Hiroshima University School of Medicine in each group. 3) The amplitude values were derived from one half of the total diurnal variation of heart rate. The amplitude was significantly larger in patients without physical disability than in those with physical disability, regardless of accompanying dementia. This finding is a probable result of diminished autonomic nervous system activity, especially sympathetic nervous system activity in patients with physical disability. 4) The acrophase indicated the time when heart rates were at their peak above the mean. The acrophase showed a significant delay in patients with dementia, compared with that of patients without dementia. This result suggests that impaired central autonomic nervous system which regulates the acrophase of periodicity is present in patients with dementia.

key words: the elderly, 24 hour electrocardiographic recording, circadian rhythm of heart rate, dementia, physical disability

(Jpn J Geriat 25: 408-412, 1988) 